\title{
Religious Self, Religious Other: Coformation as a Model For Interreligious Education
}

\author{
Jennifer Howe Peace
}

\begin{abstract}
What does adequate preparation for the next generation of religious leaders and educators look like, given the complex multireligious context in which graduates will serve? This is the core question addressed in this chapter. To explore the question, I draw on a decade of experience as associate professor of interreligious studies at Andover Newton Theological School where I co-founded CIRCLE (the Center for Interreligious and Communal Leadership Education). The key to instilling interreligious competency is moving from a model of formation to a model of coformation. Coformation in this context is a term I coined to describe the model developed at CIRCLE that privileges learning with diverse religious communities over learning about the religious other. CIRCLE classes, shared between Hebrew College and Andover Newton, were co-designed, co-taught and jointly attended by Jewish and Christian faculty and students. The model detailed here creates a blueprint for both individual and institutional transformation towards an ethos of interreligious understanding.
\end{abstract}

\section{Introduction}

One of the enduring insights of my own intellectual formation in the historical and cultural study of religions is that "we know by way of contrast." This building block of knowledge applies not only to concepts and ideas but also to our sense of identity. In other words, "I" can be defined in many ways, but one primary way to define myself is to notice that "I" am not "you." While this simple binary is an essential part of the earliest differentiation each infant makes as he or she begins to make sense of the world, it can create problems when taken to an extreme. Distinguishing between the healthy process of differentiation and meaning-making, versus a pathological commitment to two inviolable categories of $u s=$ good and them = evil is essential. Understanding and dismantling what Jonathan Sacks refers to as "pathological dualism" is at the heart of 
my approach to interfaith education in the context of seminary formation. ${ }^{1}$ The story of how this central concern might translate into a model for interreligious education is the focus of this chapter.

Between 2008 and $2018 \mathrm{I}$ had the privilege of being at the heart of a remarkable initiative to reimagine seminary education for a multireligious world in my position as founding co-director of the Center for Interreligious and Communal Leadership Education (CIRCLE), a shared initiative between Andover Newton Theological School (ANTS) and Hebrew College (HC). This work began with the providence of proximity, thanks to the nearby location of Hebrew College in 2002 and its rabbinical school, launched in 2003. However, proximity alone does not ensure creative partnership. The interreligious work between the two schools developed over many years of deliberate relationship building, ongoing financial commitments, and the combined intellectual and spiritual resources of our two communities. ${ }^{2}$

Our quest began with a question: What does adequate preparation for the next generation of religious leaders and educators look like, given the complex multireligious contexts in which our graduates will serve? Significantly, the first constituents to pose this question in a serious way were students. Betty Ann Miller, a rabbinical student, began to wonder what, if anything, the formation for ministry process taking place a few hundred yards across the hill at Andover Newton had to do with her own rabbinic training. So she looked for a conversation partner and soon her personal quest became a collective journey. This group of pioneering students, Jewish, Christian, and Unitarian Universalists (UUs), called themselves Journeys on the Hill, or Jотн. Their peer-led conversations about both the practical and theological concerns associated with

1 Jonathan Sacks, Not in God's Name: Confronting Religious Violence (New York: Schocken, 2015), 51. "Dualism comes in many forms, not all of them dangerous. There is the Platonic dualism that differentiates sharply between mind and body, the spiritual and the physical. There is the theological dualism that sees two different supernatural forces at work in the universe. There is the moral dualism that sees good and evil as instincts within us between which we must choose. But there is also what I will call pathological dualism that sees humanity itself as radically, ontologically divided into the unimpeachably good and the irredeemably bad. You are either one or the other: either one of the saved, the redeemed, the chosen, or a child of Satan, the devil's disciple."

2 In particular, the leadership of founding co-directors Or Rose from Hebrew College and Gregory Mobley from Andover Newton has been essential to the evolution and success of this work. The addition in 2014 of Islamic-scholar-in residence Celene Ibrahim and CIRCLE administrator Soren Hessler allowed the work to expand in new ways. CIRCLE was also supported by the efforts and leadership of key administrators, faculty, board members, and dedicated students at both schools. 
formation for religious leadership created the template for what became the CIRCLE fellowship program, a cornerstone of the Center's work. Under the auspices of this joint program, up to twelve CIRCLE fellows are selected through a competitive application process to participate in a yearlong process of interfaith learning and leadership. The fellowship involves both professional development sessions for the whole cohort as well as individual initiatives led by pairs of fellows, designed to increase positive relations across religious lines. While the particular story of how interreligious education became integral to ANTS and HC is perhaps idiosyncratic, the underlying assumptions, attitudes, strategies, and vision that undergird our approach may be instructive for other educators looking to effect institutional change in their own settings.

\section{Part I: From Education to Coformation}

In fall 2011, at the beginning of my third year with CIRCLE, I was invited to contribute an article to Colloquy magazine, a publication of the Association of Theological Schools (ATS), the largest accreditor of seminaries in North America. The focus of the issue was "multifaith education initiatives." While crafting a piece to describe the details of our curricular design and articulate what makes it distinctive or new, I realized that ultimately we were not just interested in adding new classes or opportunities for interfaith engagement to an already full schedule of courses and requirements. Rather, more radically, we hoped to influence the conversation and ultimately shift the paradigm about what constitutes adequate seminary education.

Thinking back to my own experiences in both seminary and doctoral studies, I understood that training for ministry and related religious leadership roles was, at its best, a profound formation process. Beyond learning the essentials of history, theology, ethics, the Bible, pastoral care, etc., seminary education is about forming a person. What was new about the model we were developing at CIRCLE was the fundamental assertion that we cannot form our religious leaders and educators in monoreligious isolation. The religious blinders of my own seminary training, revealed through what was explicitly or implicitly left out of the curriculum, gave me the impression that everything I needed to know or be able to do was fully contained in the teachings and traditions of fellow Christians (and, more often than not, white, male, Protestant Christians). In a world where religiously motivated violence and polarizing rhetoric rooted in religious stereotypes dominate the daily news, I am convinced that this model is inadequate for the current realities and demands that our graduates face (if indeed it was ever adequate). 
The theory driving CIRCLE's work posits the essential role of learning with the "religious other" as we construct a clearer sense of our "religious self." This contrasts with the dominant world religion paradigms where learning about the religious other is the norm. The emphasis on religious literacy at the heart of this model is essential, but it is not sufficient. In the opening to my article in Colloquy I coined the term "coformation" to signal the new paradigm of the model we were promoting:

To add the prefix "co" to "formation" and apply it to seminary education is to assert that students are not formed in isolation but in connection to a dynamic web of relationships. Making formation an intentionally interfaith process reflects the reality that our particular beliefs exist in a larger and complex multireligious (and nonreligious) human community, a community we want to prepare our students to both encounter and engage on multiple levels - theological, ethical, and pastoral — as community organizers, educators, preachers, and citizens. ${ }^{3}$

Beyond the relational skills and civic priorities inherent in this model, the term "coformation" signals another fundamental aspect of this work for me-the inner work that is part of forming the whole person. A key theological insight that underpins my commitment to interfaith education as part of seminary formation is the assertion that interreligious engagement is a way of being Christian. Rather than being merely tangential to faithful Christian life, how we understand and treat our religious neighbors is central to it.

In my doctoral training in the Historical and Cultural Study of Religions program at the Graduate Theological Union, my work was anchored by a focus on Christian spirituality even as I explored similarities and differences across religious traditions. Attention to my own religious life and the spiritual practices that animate it is fundamental to the process of forming my sense of self as a Christian. Coformation is a process of learning alongside religious others, attending to both the external and internal demands of coming to know the religious other in relation to the religious self. Attending to the inner dimensions of one's own spiritual formation, while prioritizing interreligious relationships in the process of training future religious leaders, is an essential part of the equation.

3 Jennifer Peace, “Coformation Through Interreligious Learning," Colloquy 20, no. 1 (2011): 27, accessed October 12, 2019, http://www.ats.edu/uploads/resources/publications-presentati ons/colloquy/colloquy-2011-fall.pdf. 
One oft-repeated sentiment in CIRCLE's work is that we are interested in helping Jews be better Jews, Christians be better Christians, UUs be better UUs, Muslims be better Muslims, and so on. This is not a model of interreligious education that skirts particularity for the sake of commonality. In fact we would argue that, on the contrary, when the work is done well, students come away with a deeper understanding and appreciation of their own identity even as they may experience some "holy envy" in the face of the practices and commitments of their fellow students from different religions.

Two anecdotes from the early years of our program illustrate this point. The first occurred in the context of our CIRCLE fellowship program, when we were still in the early weeks of the program and the cohort were getting to know each other. As we shared stories, Dan, an articulate rabbinical student, talked about his deep relationship to Judaism and what he appreciates about it. Following his comments Tim, one of the Christian students, said, "Hearing you describe what you love about Judaism makes me want to take the irony out of my voice when I talk about Christianity." Rather than only focusing on critiques of his tradition, Tim was moved to talk about what he finds beautiful in Christianity or, as Tim put it, a "theo-aesthetics" of his faith.

The second illustration of the relationship between personal formation in this process of coformation comes from the classroom. I co-taught a yearlong class on Jewish-Christian relations with my colleague from Hebrew College and CIRCLE co-director, Or Rose. One student, Greg, came into the class with a lot of confidence about his knowledge of the topic. He described himself as an interfaith minister and shared with the class the fact that he had been married for many years to a Jewish woman. Yet after a year of conversation, reflection, and reading, Greg arrived at an unexpected revelation. He had come into the class with a deep appreciation for the similarities across religious traditions, but as he wrote in his final reflection paper:

What I had yet to realize was that there is even more need to understand and appreciate each other's differences, and in the process, move beyond tolerance, and beyond simply seeking the familiar. Not everything is a commonality, and that is perfectly okay. In fact, it is necessary. In our difference lies our dimensionality, our depth, our richness.

As a result, Greg was inspired to explore his Baptist roots again, with a view to the distinct contours and evolution of his own religious identity. I like to use the analogy of a potluck supper when I talk about interfaith engagement; understanding and owning your particular religious identity is akin to bringing your own dish to the interfaith table. 
I often encounter students, like Greg, who come to interfaith work with a default emphasis on sameness. If "sameness" is the entry fee for interreligious relationships, religious commitment and particularity can be seen as antithetical to that goal. While there is typically an altruistic impulse behind this emphasis on sameness, it reveals an implicit assumption that difference is threatening. In my approach to interfaith education, while underscoring our shared humanity and the dignity that affords each of us, an important counterbalance is to dive deep into the irreducible differences that distinguish communities and individuals. An interfaith leader is someone who understands that these differences are to be safeguarded and celebrated rather than erased or flattened.

Part II: Interfaith Education and Transformative Learning

Implicit in the idea of coformation is an expectation of change. Genuine learning is a transformative process. Max Stackhouse, former professor of ethics at Andover Newton, once remarked that to truly be a Christian one must be continually open to conversion. When I did fieldwork for part of my doctoral research at a Benedictine abbey, I saw this sentiment reflected in the community's vow of conversatio morum, which they interpret as a daily openness to change. ${ }^{4}$ This posture of openness coupled with a sense of epistemological humility is essential for learning and essential for the model of interreligious coformation that we are committed to at CIRCLE.

As a professor, I've had the privilege over the years of watching students experience those moments of awe when a genuinely new insight takes hold and they sense that who they were when they came into the class has been altered or impacted in some significant way. On a certain level, the classroom is a protected space where students are free to explore new ideas and follow lines of thought. They can trace the implications of their theories and theologies yet they are spared from the consequences of such thought experiments. Imagining themselves tackling complex interreligious dilemmas from the relative

4 "The three vows taken by a Benedictine, presented by St. Benedict in Chapter $5^{8}$ of the Rule are: Stability, Conversatio Morum and Obedience. The vows of Stability and Conversatio Morum are unique to Benedictines. Stability implies not only binding oneself to the physical 'place' and land that is Regina Laudis, but also the personal identification with the spirit and aspirations of the community. Conversatio Morum, rooted in the Latin 'conversatio' complements Stability, and asks that the nun be willing 'to change' every day of her life." Abbey of Regina Laudis, "Final Profession of Mother Alma," accessed October 2, 2019, http://abbeyofreginalaudis.org/ceremonies-MotherAlma.html. 
safety of the classroom allows students to create mental muscle memory, preparing them for analogous scenarios they may encounter beyond the classroom. To train religious leaders with the confidence, curiosity, and capacity to work across religious lines on complex questions, we need to attend to the explicit, implicit, and null curricula in our seminaries.

"Our experiences change us." In a class I was teaching with Or Rose and Celene Ibrahim on interfaith leadership in the Boston area, Basma, a Muslim student from Egypt who sat in the back row, offered that simple but profound observation. She was talking about her own experiences growing up in a Muslim majority country where all her significant interactions were with fellow Muslims. Coming to the United States with her husband for school, she had myriad new experiences with people from various religious backgrounds. In fact, Basma had become a CIRCLE fellow and had spent the year co-leading a peer group with a Christian (Brethren) student from Andover Newton. The topic was on portrayals of the religious other in scripture and because of the expertise in the peer group they had looked at Jewish, Christian, and Islamic texts in Hebrew, Arabic, and English. Basma's comment reminded me of the importance of thinking carefully about the kinds of experiences we create for our students.

Interreligious education is understood in many different ways. In some seminaries in particular it is located squarely under the auspices of comparative theology. ${ }^{5}$ In many secular college and university settings, religious literacy is the dominant paradigm. ${ }^{6}$ CIRCLE's approach focuses on the broader process of formation for ministry, with an emphasis on the power of "interreligious learning through relationship building." When students are in relationship over time (students spend anywhere from two to six years in degree programs at ANTs or HC) the kinds of questions they ask and the kinds of answers they offer shift and deepen. Knowing that your conversation partner both understands and appreciates you as a person creates the possibility for the kind of trust and vulnerability that can lead to transformative learning.

My own training as an historian of religions influences my approach to interreligious education. History of religions is an interdisciplinary comparative approach to a diverse range of concerns related to how traditions have

5 See Francis x. Clooney "The New Comparative Theology: Interreligious Insights from the Next Generation" (New York: Continuum, 2010), or Catherine Cornille, The Im-Possibility of Interreligious Dialogue (New York: Crossroad, 2008).

6 See Stephen Prothero, Religious Literacy: What Every American Needs to Know-And Doesn't (New York: HarperOne, 2008), or Diane Moore, Overcoming Religious Illiteracy: A Cultural Studies Approach to the Study of Religion in Secondary Education (New York: Palgrave Macmillan, 2007). 
developed, interacted, and impacted both individuals and communities over time. For me, understanding stories from the past offers paradigms and patterns of thought that can provide insights and tools for analyzing current interreligious relations.

Beyond intellectual curiosity, my interest is fueled by an ethical concern that began to form when I was a young college student majoring in South Asian studies. As I read accounts of the partition of India in August 1947 and the massive violence that erupted along the border, my questions centered on how community is created and destroyed. How did those who lived side-by-side before the partition shift from being defined primarily as neighbors to being defined narrowly through the lens of religious identity? What turns a neighbor into an enemy seemingly overnight? How are such breaches repaired? Of course these are not questions confined to history books. They come up again and again when we try to piece together what happened in Rwanda in April 1994 or in Srebrenica in July 1995, to name just two stark and relatively recent examples.

Given both past and contemporary examples of communal violence, particularly where the lines of division are drawn in religious terms, I would argue that cultivating interreligious understanding among our future religious leaders is an ethical imperative. Those of us who identify as members of a religious community have a responsibility to both acknowledge and decry the violence done in the name of the traditions we claim. It is inadequate and perhaps immoral to educate future religious leaders without teaching the skills, encouraging the attitudes, and providing for experiences that will prepare them both to work for peace in the midst of religiously motivated violence and to be "repairers of the breach" in the wake of communal violence. ${ }^{7}$ I would argue that one of the central commitments of an interreligious leader is to safeguard the wellbeing and religious identity of the "other," particularly those from vulnerable religious minorities. ${ }^{8}$

The lines that divide us can be of course drawn in many different ways, and our identities are always more complex than our religious affiliations. This is where interfaith educators can draw on and contribute to scholarship related to the intersectionality of identity, as well as scholarship focused on defining and dismantling systems of oppression such as racism, sexism, homophobia,

7 The phrase comes from Isaiah 58:12 (NRSV). "And your ancient ruins shall be rebuilt; you shall raise up the foundations of many generations; you shall be called the repairer of the breach, the restorer of streets to dwell in."

8 For an exploration of the role of interreligious dialogue in civil society see Oddbjørn Leirvik, Interreligious Studies: A Relational Approach to Religious Activism and the Study of Religion (New York: Bloomsbury, 2014). 
anti-Semitism, ableism, ageism, and other forms of hatred based on particular identity categories. My own background in feminist studies, coupled with my experiences as a woman working in the male-dominated spheres of academia and religious leadership, have led me to see the parallels between the work of developing a feminist consciousness and the underlying tasks of interfaith education - both are forms of consciousness-raising. Ultimately, raising one's own consciousness cannot be mandated, only encouraged. My task as an educator is to set up the conditions where students feel safe enough and curious enough to accept the invitation to remove their blinders and be changed.

\section{Part III: Curriculum Design and Institutional Transformation}

Having articulated CIRCLE's vision and some key insights that shape our approach to interfaith education, this section outlines the curricular and co-curricular model that embodies these ideals. A student-led peer group and an ad hoc offering of joint courses and campus events were already underway when I came to Andover Newton in 2008. With the establishment of CIRCLE we began to develop a more strategic long-term vision for how this work could generate wider institutional change. The initial grant proposal to the Henry Luce Foundation framed the goal of our work in broad terms. Beyond adding new resources to develop our interfaith programming, we focused on how the Center might be a catalyst for institutional change-nurturing an ethos of interreligious understanding on both campuses.

Students from ANTS and HC laid the groundwork for the institutional change through their curiosity and entrepreneurial energy, with which they reached out across the two campuses to form a new interreligious student group, Journeys on the Hill (Јотн). The students quickly found allies among the faculty, who began to offer a handful of joint courses. The work continued to develop, gathered momentum, and eventually led to grant applications. With the infusion of significant financial resources in 2008, thanks to the Henry Luce Foundation, CIRCLE was established, creating the essential interinstitutional infrastructure on which the work could be built.

Campus programs, a joint fellowship program, and joint courses were the three primary foci of CIRCLE's work that most impacted and shaped curricular changes. It is worth noting the key features of each of these initiatives before discussing some of the resulting curricular and institutional changes:

\subsection{Cross-campus Programming}

CIRCLE often describes our two campuses as a "living laboratory" where we can explore various models of interreligious engagement. Campus 
programming is the crucible where new ideas are born, some of which find their way into the life of the schools. Broadly speaking, our campus programming typically serves one or more of three goals: jointly acknowledging or celebrating key moments in the liturgical life of our respective traditions; lectures, panels, or conferences that increase religious literacy or interreligious understanding; and activities, events, or programs focused on strengthening or building relations across religious lines. These goals provide a kind of plumb line when we are considering sponsoring new programs.

Beyond the optional programs CIRCLE sponsors, co-sponsors, or supports each year, the annual event with the broadest institutional impact is our Joint Spring Community Day. This event evolved out of an existing practice at ANTS of holding two "community days" each year, in the fall and in the spring. After ANTS invited HC to participate in its joint day of service learning, the event evolved into an important shared tradition planned by CIRCLE fellows with guidance and input from the co-directors. It reflects a significant joint institutional commitment, as both schools close down operations for the day and "require," or at least strongly urge, all students, staff, and faculty to participate in a full day of relationship-building, shared meals, and shared learning. For some on our campuses, this is their first introduction to students from the neighboring school and it often leads to new connections and new commitments that sow the seeds for new initiatives, programs, and fellowship pairs in subsequent years.

Another example of how a singular event can become a shared tradition is the annual CIRCLE-sponsored celebration of Sukkot, an autumn Jewish holiday that has a built-in expectation of welcoming the stranger. This creates an authentic opportunity for Andover Newton students to visit Hebrew College early in the semester and get a peek into a particular Jewish practice while sitting in a Sukkah and experiencing the hospitality at the heart of this holiday. It has also become a great time to introduce our new CIRCLE fellows and invite students to participate in the range of peer-group opportunities that the fellows lead each year. After doing this together for many years, the annual celebration of Sukkot has become an anticipated shared tradition.

A final example illustrates how co-curricular programs can ultimately impact curricular design. This example underscores the importance of cultivating a culture of innovation and entrepreneurial energy to generate a vibrant model of interreligious education. One year, we had a student, Kurt, who was interested in the criminal justice system. He initiated a relationship with a Boston-based organization, Partakers, which organizes volunteers into teams of mentors for incarcerated individuals who are pursuing their GEDs or college 
degrees. ${ }^{9}$ To ensure the continuity of this collaboration, before graduating, Kurt worked with CIRCLE's co-directors to fold this work into the CIRCLE fellowship program. For many years, the program continued with a rotating set of two students (one from HC and one from ANTS) providing leadership for a "prison justice and ministry peer group." ANTs faculty member Brita GillAustern, professor of psychology and pastoral theology, participated in the group one year, and this led Gill-Austern to offer a credit-bearing class on prison justice. This is an example of taking a student-driven initiative and moving it into the curricular heart of the school. While not every program or event becomes a shared tradition or a part of the curriculum, the creative range of programs each year, influenced by the inclinations of students, in conversation with the experience of CIRCLE's co-directors, allows for a dynamic interaction of new ideas that influences the ethos on each campus.

\subsection{CIRCLE Fellowship Program}

This model of "learning with rather than about" each other guides our work both within and beyond the classroom, and it has become a key principle in our fellowship program. Over the years the fellowship program has been modified, refined, and altered to suit shifting resources and changes in our model of interreligious work, but it has remained a central and distinct feature of our program since its inception. One of the goals of CIRCLE programming in general is to provide multiple entry points and levels of commitment to honor the range of goals and experiences of our seminary students. On the spectrum of participation, students can attend a single event, take a joint class, join a yearlong interfaith peer group, or, at the most time-intensive end of the spectrum, apply to become a CIRCLE fellow.

Two or three students (each from a different religious background) apply to the program as a team. This requires that students have begun the process of relationship building that is at the heart of our model..$^{10}$ It also ensures a certain amount of parity, a core value of the work, even in the initial planning stage. We ask students to conceive of a topic of shared concern where their

9 For an overview of Partakers' “College Behind Bars” mentoring program, accessed October 12, 2019, see http://partakers.org/site/college-behind-bars/.

10 While it is beyond the scope of this chapter to go into details here, when designing programs that rely on relationship building it is important to consider the power dynamics among students and how racism and other forms of discrimination might disadvantage or even preclude certain students from participation. In our own program I have become increasingly aware of how biases can get in the way of forming the initial partnerships required to apply to become a CIRCLE fellow. 
respective traditions inspire, motivate, or equip them in some way to tackle the issue at hand. Fellowship projects over the years have focused on environmental concerns, shared text study, artistic expression (from singing to poetry to multimedia art as a mode of spirituality), prison justice, issues of women's leadership, and LGBTQ issues, to name a few. We have found that this model allows for powerful coformation experiences that radically broaden how students understand their roles and obligations as future religious leaders.

In addition to their leadership around a topic of shared concern, fellows engage as a cohort in a yearlong leadership development program designed by CIRCLE'S co-directors. One goal of the regular cohort meetings is to create a sense of community that can extend beyond graduation so that former CIRCLE fellows might become resources and colleagues out in the field. In addition to sharing personal stories and exploring theological questions, these sessions include everything from the nuts and bolts of running a successful interfaith event to strategies and tools for facilitating difficult conversations and an overview of grant-writing.

To expand the model beyond Jewish, Christian, and Unitarian Universalist contexts, we actively built relationships with Muslims in the greater Boston area. To this end, in 2012 I formed an intra-Muslim women's group with the support and partnership of Islamic scholar Celene Ibrahim. We called our group "Third Thursdays," and met together monthly for a year of conversation and relationship-building, focusing on both the needs and resources of the wider Muslim community. Out of these conversations we decided to invite "Muslim community fellows" to apply for our CIRCLE fellowship program. Interest and participation increased each year and eventually laid the groundwork for a historic institutional decision to jointly appoint Celene Ibrahim as our third CIRCLE co-director and Islamic Scholar-in-Residence at HC and ANTS.

In the first years of the fellowship program we provided students with a large annual stipend and met weekly as a cohort. Over the years we've reduced the stipend to a sustainable amount and created endowments to support them, while also cutting back from weekly cohort meetings to monthly sessions. The importance and impact of the innovation and leadership of these fellows cannot be overstated in terms of the impact on the ethos of our campuses over the years, and we are currently in the process of conducting a qualitative study to evaluate the impact of the fellowship program on alums, conducting interviews and sending surveys to what is now more than a hundred former fellows from both HC and ANTs. Initial feedback from fellows speaks to the power of the program and its relevance in their own work as religious leaders. Reflecting on her own changing paradigm for interfaith work influenced by CIRCLE's program, one Muslim fellow commented: 
I think most of my interfaith work was one-directional; people would come to the mosque looking for information on Islam and we would deliver that information. The models of interfaith partnership modeled at CIRCLE are different: often a single issue is engaged from multiple faith perspectives, with each partner learning equally about their own tradition in the process. I've really appreciated this approach as more collaborative and more enriching than the models I've been using. ${ }^{11}$

\subsection{Joint Courses}

As early as the founding of јотн, students began agitating for shared learning opportunities, not just as co-curricular options, but as credit-bearing courses. They found willing partners on both campuses, particularly Or Rose from Hebrew College and Gregory Mobley from Andover Newton, who provided critical early leadership and taught many joint courses over the years.

As more and more faculty became engaged and inspired by co-teaching, we began to systematize the offerings and create a coherent scope and sequence for students who wanted to leave seminary or rabbinical school with a solid grounding in interreligious leadership. When we considered the courses that had been particularly successful over the years, we noticed they seemed to fall into one of three areas: shared text study, practical or pastoral concerns, and social justice topics. These were areas where joint classes clearly enhanced mutual learning and where there appeared to be a strong sense of mutual motivation. These were also areas where we had complementary faculty expertise on each campus that allowed for joint course design and co-teaching. A final essential ingredient was that these areas appealed to a large number of students from each campus and contributed to their respective degree programs. In addition to these three areas, we began to offer a set of courses focused specifically on understanding the many dimensions of interfaith leadership. Identifying core areas for co-teaching has allowed us to offer a dynamic range of specific courses that speak to student and faculty interests, while providing some consistency and predictability to the kinds of courses we offer.

Institutionalization necessarily takes time and involves many stakeholders, including board members, administrators, faculty, staff, and students. While we

11 Jennifer Peace, "Grant Report: July 1, 2013-June 30, 2014." Unpublished grant report to the Henry Luce Foundation (May 15, 2014), 4. 
consciously attend to parity in all our work, progress toward institutional change has necessarily followed distinct if parallel trajectories at Hebrew College and Andover Newton. Because of my own location, I will focus primarily on the shape of this path at Andover Newton.

One of the great success stories of CIRCLE's work toward institutionalization at Andover Newton was the creation of a tenure-track faculty position in Interfaith Studies. It is the first position of its kind in Andover Newton's history and one of a small handful of similar positions across the country. The new position was created with the unanimous approval of both the faculty and the ANTS Board of Trustees in June 2012. After going through the search process as the incumbent candidate, I became the first person to be hired for this position. In 2015, I received tenure and promotion to my current title of Associate Professor of Interfaith Studies. Anchoring the work under the auspices of a tenured faculty member was an important step in establishing its centrality in the academic heart of the school.

With leadership from Dean of Faculty, Sarah Drummond, interfaith education moved from a series of ad hoc courses to the center of our academic programs. Interfaith courses were initially electives, but during a scheduled curriculum revision process we added an expectation that all MDiv students would take at least one class with an interfaith focus. The next step was the creation of a five-course "Certificate in Interfaith Leadership." CIRCLE's co-directors designed the interfaith certificate jointly with the needs and curricular models of both institutions in mind. However, it was an easier adaptation for ANTs because we had previously established a number of certificates in other areas. At HC adding a certificate requires creating a new academic category, which ultimately meant it was never fully implemented as a joint certificate program. We learned important lessons about the challenges of coordinating curricular changes across schools with very distinct educational designs. We applied these lessons when CIRCLE turned its attention to the task of creating parallel interreligious MA programs, a degree with greater "currency" both on our two campuses and in the wider world.

In a major milestone for institutionalization, ANTS and HC both launched their own versions of new master's degree programs in 2015. Andover Newton's Master in Global Interreligious Leadership (MGIL), approved by ATS, is a pioneering program that attracted a diverse group of students to its inaugural class in fall 2015. Andover Newton's version of the degree has a cohort of Muslim, Christian, and UU students, and there is a second cohort of Jewish students in Hebrew College's program. The new MGIL MA degree is described in our report to the Luce Foundation: 
The goal of this program is to help current and future communal leaders develop the knowledge and skills to serve effectively in an age of unprecedented interaction among people from different religious and cultural traditions. MGIL addresses an urgent need in the educational formation of emerging and veteran clergy and others serving as religious educators, community organizers, and nonprofit and civic leaders. The program is designed in such a way that students from each school will earn a Master's Degree from Andover Newton or Hebrew College, and a certificate from the other institution. The program can be completed in 18 months at either school, with various components available online. ${ }^{12}$

The MGIL MA programs were built on the foundation of strong relationships fostered through cross-campus events, jointly taught courses, shared faculty development, and inter-institutional structures that allowed for ongoing communication and shared decision-making.

Faculty buy-in, administrative leadership, and curricular and co-curricular programs are all essential ingredients of institutionalizing interreligious understanding, but one added and often overlooked ingredient for this work is physical space. Our work evolved over time through sharing our respective spaces, but a long-standing vision for creating a space specifically dedicated to this work goes back as far as the first grant to the Luce Foundation in 2008. After Nick Carter completed a ten-year term as president of Andover Newton and incoming president Martin Copenhaver chose to live off campus, the historic President's House was no longer needed for housing the college president. The idea of designating the President's House as a dedicated space to create a vibrant center for interreligious living, learning, and research for Jewish, Christian, UU, and Muslim community members on our hilltop campus inspired many, including the Andover Newton board of trustees. In summer 2015 the board voted unanimously to do just that.

"CIRCLE House" has created a much-needed community-building space for Hebrew College, ANTS, and our Muslim partners. It has extended the possibility for new partnerships as community-based organizations doing innovative interfaith and/or Islamic educational work affiliate with us. It offers a natural space to host interreligious events and group meetings. The decision to convert the President's House into a center for interreligious learning also signals an ever-deepening institutional commitment to interreligious work. Perhaps

12 Celene Ibrahim, and Or Rose. "Annual Grant Report." Unpublished grant report to the Henry Luce Foundation (May 2015), 8. 
most importantly, it has created a new shared space on our campuses where students can bump into each other and get to know each other in the kind of relaxed, informal setting that is essential to building genuine friendships across lines of religious difference. The world is in desperate need of more spaces such as these.

As a Christian educator, what is at stake in interfaith education is related to what is at stake for seminary education in general. I see this work as a paradigm shift in our understanding of and relationship to the "religious other." In earlier days (and still in some seminaries today) exposure to the religious other comes primarily through the lens of missionary accounts or classes outlining the tenets of other faiths only as a tool for proselytizing. ${ }^{13}$ The approach charted by CIRCLE goes beyond a more neutral religious literacy approach, found in many programs, to a model of transformative learning that results in both better religious leaders and better interreligious leaders. ${ }^{14}$ Deep knowledge of one's self in relation to the religious other is no longer only an option but an obligation, if our students are going to responsibly and effectively engage in the pressing needs and current issues of our religiously diverse twenty-firstcentury context.

After a decade co-directing CIRCLE, I am more convinced than ever that interfaith education is an essential part of seminary formation. The trajectory of CIRCLE's work, from ad hoc student-led programs to a new tenure-track faculty position and an accredited MA in Global Interreligious Leadership, is particular to our context, yet the need for similar innovations and the adoption of interreligious coformation as a key paradigm for seminary education is widely applicable.

My greatest hope is that the work we have done through CIRCLE might serve as a model or source of inspiration for others, even as we learn from other models how to deepen and develop our own work. This interest in being part of a dynamic conversation has led to my work in establishing new platforms where these conversations can take place on the national level. In 2013 I cofounded with Homayra Ziad the Interreligious and Interfaith Studies group as

13 Auburn Seminary released a study in 2009 on the state of multifaith education in American theological schools. Summarizing the results, the report found that "multifaith education enhances proselytizing" was one of the top three rationales for American seminaries to include classes in this area. Auburn Seminary, Center for Multifaith Education, Beyond World Religions: The State of Multifaith Education in American Theological Schools, 2009, accessed October 19, 2019, http://www.auburnseminary.org/seminarystudy.

14 It is interesting to note that the other two rationales Auburn found for "multifaith education" were that it "makes better religious leaders," and that it "strengthens faith." 
part of the American Academy of Religions (AAR). Due to the overwhelming positive response and interest in this group at the AAR, I founded the Association for Interreligious and Interfaith Studies (AIIS) in 2017 as a scholarly society dedicated to developing and exploring the potential of this emerging paradigm in the study of religions and its implications for both educational institutions and civic life.

Many of the details of how this work happens falls under the radar of major news outlets or academic journals, yet the ripple effects from one program, one class, one changed heart, one institutional transformation play out every day in countless ways. I attempted to capture a glimpse of these ripples in an annual grant report on our activities to the Henry Luce Foundation:

I am keenly aware of both the slow pace of making institutional change and the urgent need for transformed leaders working across religious divides. In the two years covered by this report alone, we have seen countless news stories of religious bigotry eclipsing our higher civic values: From the national controversy that erupted in 2010 over the Park 51 Community Center in NYC, to Peter King's anti-Muslim congressional hearings, to the shootings this August in Oak Creek, Wisconsin at a Sikh Gurdwara that left six people dead.

In each of these moments when fault lines in our country's civic life have been exposed, we have also seen people rise up in acts of courage and vision - people who step into the breach and act as agents for healing. When the Park 51 controversy erupted, a Jew, a born-again Christian, and an atheist teamed up and committed hundreds of hours of time to help counter the false propaganda about the Park 51 (one of whom, Josh Stanton, cofounded CIRCLE's online publications, the Journal of Interreligious Studies and the "State of Formation" blog site).When Congressman Peter King (R-New York) convened hearings on the "extent of the radicalization of American Muslims," Muslim, Jewish, and Christian leaders from the ICPL (Interreligious Center for Public Life, founded by ANTS and $\mathrm{HC}$ ), joined with others to send a joint letter of concern to elected officials, posted articles condemning the hearings, and convened conversations in their respective communities. In the wake of the killings at the Sikh Temple of Wisconsin in Oak Creek, students from the summer seminar "Building Interfaith Community and Leadership," which I co-taught with Dianna Eck, responded with letters of condolence, public letters of support, sermons, and solidarity at gatherings in local gurdwaras the week following the attack. 
All of these responses confirm my conviction that CIRCLE's work can and does have ripple effects beyond our hilltop.We are creating programming and structures, but most importantly we are nurturing an ethos of understanding that contributes to our collective ability to respond with skill and courage to acts of religious violence. CIRCLE's commitment and that of countless others to interreligious bridge-building is bolstered every time a connection is built, every time ignorance is countered with understanding, every time love and solidarity trump hatred and isolation. We can't predict when the breaches will occur, but we can and must continue to prepare leaders who are equipped for the slow, patient work of repair. ${ }^{15}$

At the beginning of this chapter I noted that the interfaith work at Andover Newton and Hebrew College began with a key question: What does adequate preparation for the next generation of religious leaders and educators look like, given the complex multireligious contexts in which our graduates will serve? Over many years of experimentation, reflection, and strategic development our questions have shifted and multiplied. We are no longer asking whether or not the competencies of interreligious leadership are necessary for adequate preparation. Instead our questions focus more on the details of "how" and "what." How can we design a curriculum to move from a model of religious formation to a model of interreligious coformation? How can we integrate interfaith concerns in a curriculum so that they do not remain peripheral or optional? What curriculum designs, educational programs, and pedagogical strategies best serve this work? What does a competent religious leader need to know or do to effectively work with colleagues and community stakeholders across religious lines? These are not questions we can answer alone. The many contributions in this book each help to frame and fill in the details as we collectively confront these pressing questions. ${ }^{16}$

\footnotetext{
15 Jennifer Peace, "Final Report on Luce Grant funding from July 2010-June 2012." Unpublished grant report to the Henry Luce Foundation (September 2012) 17-18.

16 In June 2019, Andover Newton Theological School closed its Newton, Massachusetts campus and moved operations to New Haven. Andover Newton Seminary at Yale Divinity School no longer houses the CIRCLE program. But the legacy of CIRCLE's work continues in the lives and ministries of those who were impacted by its programs as well as in the ongoing work of the Betty Ann Greenbaum Miller Center for Interreligious Learning and Leadership at Hebrew College.
} 


\section{Bibliography}

Auburn Seminary, Center for Multifaith Education. Beyond World Religions: The State of Multifaith Education in American Theological Schools. 2009. Accessed October 19, 2019. http://www.auburnseminary.org/seminarystudy.

Clooney, Francis x. The New Comparative Theology: Interreligious Insights from the Next Generation. New York: Continuum, 2010.

Cornille, Catherine. The Im-Possibility of Interreligious Dialogue. New York: Crossroad, 2008.

Ibrahim, Celene, and Or Rose. “Annual Grant Report.” Unpublished grant report to the Henry Luce Foundation, May 2015.

Leirvik, Oddbjørn. Interreligious Studies: A Relational Approach to Religious Activism and the Study of Religion. New York: Bloomsbury, 2014.

Moore, Diane. Overcoming Religious Illiteracy: A Cultural Studies Approach to the Study of Religion in Secondary Education. New York: Palgrave Macmillan, 2007.

Peace, Jennifer. "Coformation Through Interreligious Learning." Colloquy 20, no. 1 (2011): 24-27. Accessed October 12, 2019. http://www.ats.edu/uploads/resources/ publications-presentations/colloquy/colloquy-2011-fall.pdf.

Peace, Jennifer. “Final Report on Luce Grant funding from July 2010-June 2012." Unpublished grant report to the Henry Luce Foundation, September 2012.

Peace, Jennifer. “Grant Report: July 1, 2013-June 30, 2014.” Unpublished grant report to the Henry Luce Foundation, May 15, 2014.

Prothero, Stephen. Religious Literacy: What Every American Needs to Know-And Doesn't. New York: HarperOne, 2008.

Sacks, Jonathan. Not in God's Name: Confronting Religious Violence. New York: Schocken, 2015 . 